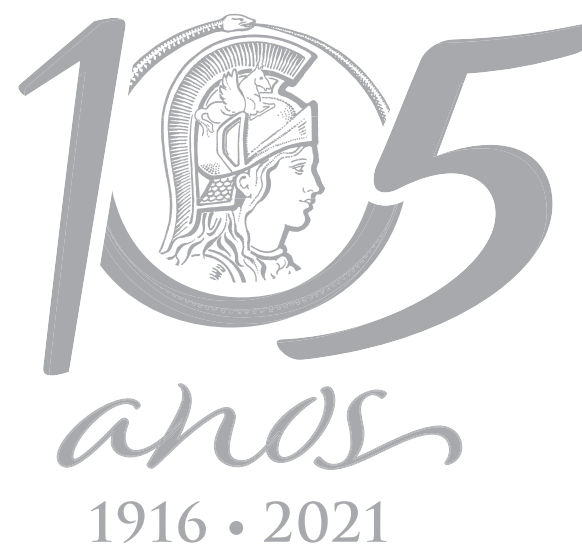

\title{
MICROBIOLOGY
}

\section{Using metabarcoding to assess Viridiplantae sequence diversity present in Antarctic glacial ice}

\author{
PAULO E.A.S. CÂMARA, GRACIELE C.A. MENEZES, OTAVIO H.B. PINTO, MICHELINE \\ C. SILVA, PETER CONVEY \& LUIZ H. ROSA
}

\begin{abstract}
Antarctica contains most of the glacial ice on the planet, a habitat that is largely unexplored by biologists. Recent warming in parts of Antarctica, particularly the Antarctic Peninsula region, is leading to widespread glacial retreat, releasing melt water and, potentially, contained biological material and propagules. In this study, we used a DNA metabarcoding approach to characterize Viridiplantae DNA present in Antarctic glacial ice. Ice samples from six glaciers in the South Shetland Islands and Antarctic Peninsula were analysed, detecting the presence of DNA representing a total of 16 taxa including 11 Chlorophyta (green algae) and five Magnoliophyta (flowering plants). The green algae may indicate the presence of a viable algal community in the ice or simply of preserved DNA, and the sequence diversity assigned included representatives of Chlorophyta not previously recorded in Antarctica. The presence of flowering plant DNA is most likely to be associated with pollen or tissue fragments introduced by humans.
\end{abstract}

Key words: Algae, Angiosperms, DNA, biodiversity.

\section{INTRODUCTION}

Glaciers and ice sheets cover about 15 million $\mathrm{km}^{2}$ globally, or about $10 \%$ of the Earth's land surface (Anesio \& Laybourn-Parry 2012). A limited number of microorganisms (bacteria, various groups of algae, and fungi) are known to be able to survive the harsh conditions within ice (Sanyal et al. 2018, Perini et al. 2019). Many of these microorganisms exhibit a range of adaptations that protect their metabolism from the damaging effects of harsh environmental conditions such as extreme temperatures and lack of liquid water (Siddiqui \& Cavicchioli 2006, Margesin \& Miteva 2011), including some of potential biotechnological interest. Some microbial communities present in glacial ice are biochemically active (Price 2000, Anesio et al. 2009, Hodson et al. 2010). However, available reports are mostly restricted to bacteria and from studies in the Northern Hemisphere (Sheridan et al. 2003, Miteva \& Brenchley 2005).

Antarctica contains most of the world's glacial ice (de Menezes et al. 2020), representing about $70 \%$ of freshwater globally (Sadaiappan et al. 2020). Formed by the accumulation of snow gradually compressed over many years, Antarctic glacial ice may provide a unique habitat for microorganisms that could have been trapped for many thousands of years (Abyzov 1993, Gunde-Cimerman et al. 2003), with the oldest ice yet drilled in Antarctica being dated to several hundred thousand years (Elzinga 2012).

In recent decades, parts of Antarctica have experienced the impacts of anthropogenic warming. In the Antarctic Peninsula region, the temperature increase already exceeds $1.5^{\circ} \mathrm{C}$ over pre-industrial temperatures (Turner 
et al. 2005), where it has led to widespread glacial retreat (Cook et al. 2017). This releases meltwater into the surrounding environment, potentially including viable biological material and propagules. Therefore, understanding the biological diversity contained in this habitat is a research priority.

To date, very few studies have addressed the biodiversity of ice-associated habitats. The majority have focused on bacteria and are mostly based on traditional culture methods (Margesin et al. 2002, Foght et al. 2004, Yallop \& Anesio 2010) or direct observation (Porazinska et al. 2004, Stibal et al. 2006). The biodiversity and adaptations of species found in some iceassociated habitats, such as glacier surface cryoconite holes (Porazinska et al. 2004) and in surface snow (Davey et al. 2019) have received research attention, and there are a small number of studies of algal communities found in glacier ice, mostly in the Northern Hemisphere and focused on the ice surface (Takeuchi et al. 2015, Stibal et al. 2017, Onuma et al. 2018). The considerable differences in physical and chemical properties of surface snow and bare ice result in very distinct biological communities being present in these two environments (Yoshimura et al. 1997, Lutz et al. 2017).

Rapid developments in molecular biological techniques in recent decades now allow the assessment of biological diversity in environmental samples based on the DNA sequences present, for instance through DNA metabarcoding using high throughput sequencing (HTS) (Rippin et al. 2018, Ruppert et al. 2019). This includes the possibility of detecting stages which are typically not detected in morphological surveys (e.g. pollen, spores, microscopic fragments and even single cells), as well as traces of environmental DNA, which may sometimes be preserved for many years (Barnes \& Turner 2015). Conversely, these approaches do not allow assessment of viability or activity, while putative identifications depend on the level of diversity coverage achieved by existing databases (Darling \& Mahon 2011). To date, only a few studies (Rippin et al. 2018, GarridoBenavent et al. 2020, Fraser et al. 2018, Câmara et al. 2020) have applied HTS for assessing plant biodiversity in Antarctica, and none in terrestrial glacier ice. The aim of the current study was, therefore, to use HTS to characterize Viridiplantae DNA present within glacial ice from Antarctica.

\section{MATERIALS AND METHODS}

\section{Sampling}

We collected three glacial ice fragments of approximately $20 \mathrm{~kg}$ each were collected from the ablation zone of seven glaciers in the South Shetland Islands and the north-west Antarctic Peninsula during the austral summer of 2015/2016 (Figure 1, Table I). Immediately after collection, the external surface of the ice was sterilized following the protocol established by de Menezes et al. (2020), ice samples were then melted at room temperature $\left(\right.$ ca. $22^{\circ} \mathrm{C}$ ) for $48 \mathrm{~h}$ in sterile conditions. The water obtained was filtered using $0.47 \mu \mathrm{m}$ membranes (Millipore, USA). A total of 12-15 $L$ of ice were filtered until the membranes were saturated (ca. 4-5 L per membrane), meaning a total of three membranes were obtained from each site. Membranes were stored at $-20^{\circ} \mathrm{C}$ until DNA extraction.

\section{DNA extraction, Illumina library construction and sequencing}

Total DNA was extracted as described by Lever et al. (2015). For DNA cleaning we used the DNeasy Plant Mini Kit (QIAGEN, Carlsbad, USA) from step six, following the manufacturer's instructions. The three membranes from each sampling site were extracted separately, with the products 
obtained then being combined to concentrate the DNA. DNA quality was analysed by agarose gel electrophoresis (1\% agarose in 1× TrisborateEDTA) and then quantified using Quanti-iтTM Pico Green dsDNA Assay (Invitrogen). The internal transcribed spacer 2 (ITS2) of the nuclear ribosomal DNA was used as a DNA barcode for molecular species identification (Chen et al. 2010, Richardson et al. 2015) using the universal primers ITS3 and ITS4 (White et al. 1990). Library construction and DNA amplification were performed using the Library kit Herculase II Fusion DNA Polymerase Nextera XT Index Kit V2, following Illumina 16S Metagenomic Sequencing Library Preparation Part \#15044223 Rev. B protocol. Paired-end sequencing $(2 \times 300$ bp) was performed on a MiSeq System (Illumina) by Macrogen Inc. (South Korea).

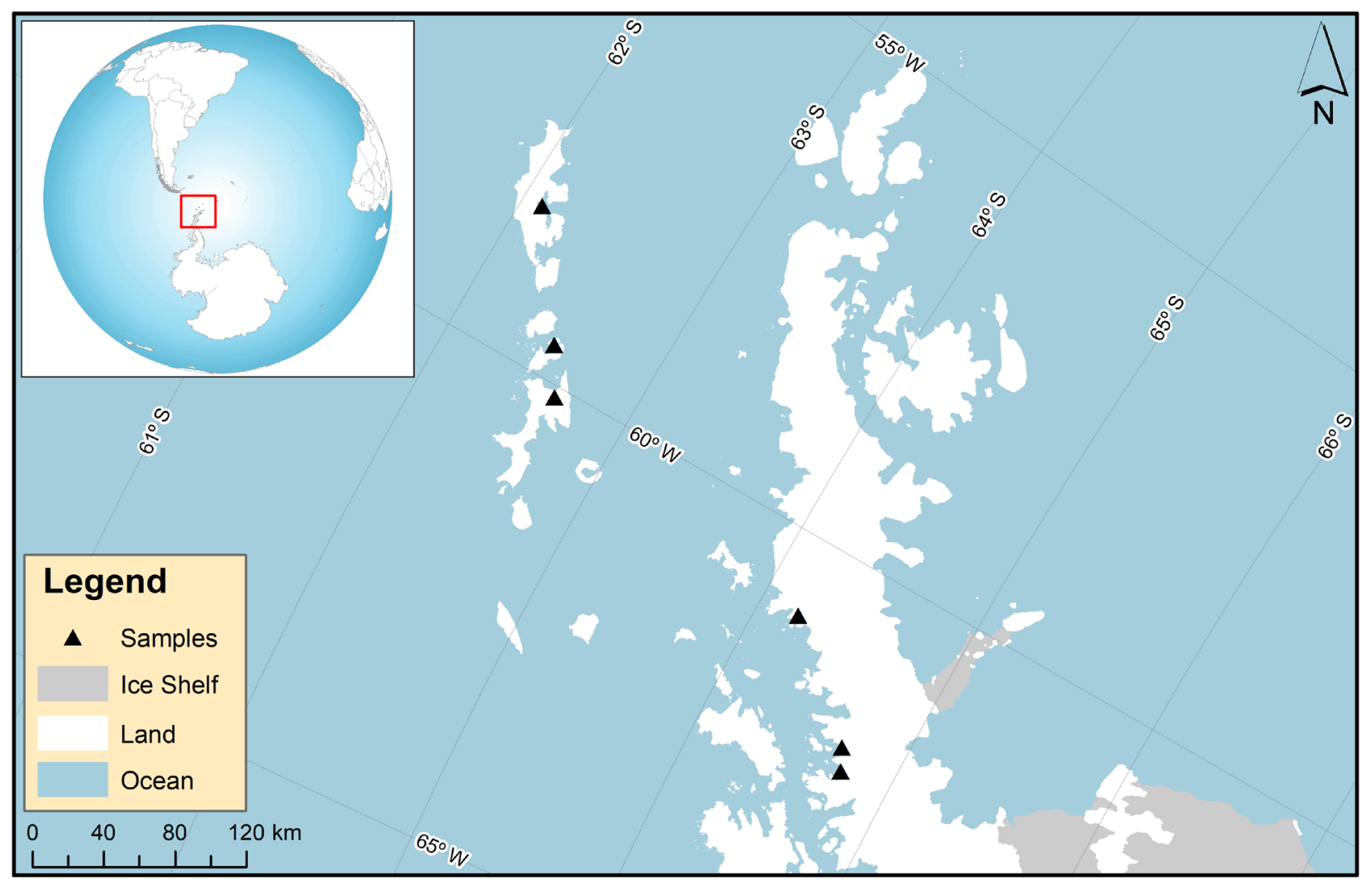

Figure 1. Map showing the sampling locations in the South Shetland Islands, KGI = King George Island, Grw = Greenwich Island, Livin = Livingston Island, Pen1 = Antarctic Peninsula 1, Pen2 = Antarctic Peninsula 2, Arctow = Arctowski Peninsula.

Table I. Sites were glacial ice was sampled in South Shetland Islands and Antarctic Peninsula.

\begin{tabular}{|c|c|c|c|}
\hline Glacier & Site & Coordinates & Code \\
\hline King George Island & Ajax/Stenhouse & $62^{\circ} 06^{\prime}$ S, $058^{\circ} 27^{\prime \prime} \mathrm{W}$ & $\mathrm{KGI}$ \\
\hline Greenwich Island & Fuerza Aerea & $62^{\circ} 30^{\prime} \mathrm{S} 59^{\circ} 38^{\prime \prime} \mathrm{W}$ & GrW \\
\hline Livingston Island & Huron & $62^{\circ} 37^{\prime} 50^{\prime \prime} \mathrm{S} 60^{\circ} 06^{\prime} 50^{\prime \prime} \mathrm{W}$ & Livin \\
\hline Antarctic Peninsula 1 & Sikorsky & $64^{\circ} 12^{\prime} \mathrm{S} 60^{\circ} 53^{\prime \prime} \mathrm{W}$ & Pen1 \\
\hline Antarctic Peninsula 2 & Leonardo/Blanchard & $64^{\circ} 42^{\prime} \mathrm{S}, 61^{\circ} 58^{\prime} \mathrm{W}$ & Pen2 \\
\hline Arctowski Peninsula & Rozier/Woodbury & $64^{\circ} 45^{\prime} \mathrm{S} 62^{\circ} 13^{\prime \prime} \mathrm{W}$ & Arctow \\
\hline
\end{tabular}




\section{Data analysis}

Raw fastq files were filtered using BBDuk version 38.34 (BBMap - Bushnell B. -sourceforge.net/ projects/bbmap/) to remove Illumina adapters, known Illumina artefacts, and the Phix Control v3 Library. Quality read filtering was carried out using Sickle version 1.33 -q 30 -l 50 (Joshi et al. 2011), to trim 3' or 5' ends with low Phred quality score, and sequences shorter than $50 \mathrm{bp}$ were discarded. The remaining sequences were imported to QIIME2 version 2019.10 (https:// qiime2.org/) for bioinformatics analyses (Bolyen et al. 2019) and the pipeline was executed for merged pair-ended sequences with the following plug-ins: vsearch join-pairs (Rognes et al. 2016), vsearch dereplicate-sequences, quality-filter q-score-joined (Bokulich et al. 2013), vsearch cluster-features-de-novo 97\% identity limit, vsearch uchime-denovo. Taxonomic assignments were determined for operational taxonomic units (OTUs) using the feature-classifier (Bokulich et al. 2018) classifysklearn against the PLANiTS2 database (Banchi et al. 2020) trained with Naïve Bayes classifier. We follow the definition of Viridiplantae of Leliaert et al. (2012).

Many factors, including extraction, PCR and primer bias, can affect the number of reads obtained (Medinger et al. 2010), and thus lead to misinterpretation of absolute abundance (Weber \& Pawlowski 2013). However, Giner et al. (2016) concluded that such biases did not affect the proportionality between reads and cell abundance, implying that more reads are linked with higher abundance (Deiner et al. 2017, Hering et al. 2018). Therefore, for comparative purposes we used the number of reads as a proxy for relative abundance.

\section{RESULTS}

The calculated rarefaction curves indicated that the sampling gave an accurate representation of the local OTU diversity in the sites where such a curve was possible to calculate (Fig. 2), for Arctowski Peninsula the curve had not completely stabilized. For sites with only one taxon (e.g. Livingston Island) it was not possible to produce a rarefaction curve.

A total of 2,007,454 paired-end DNA reads were generated in the sequencing run of which 704,819 reads remained after quality filtering, representing 16 OTUs (Table 1 I). These were assigned to 11 Chlorophyta (green algae) and five Magnoliophyta (flowering plants). Some OTUs could only be resolved at higher taxonomic level (family, order or division). The unassigned ranks refer to groups not present in the consulted databases (Fig. 3), mostly representing Fungi.

Sequences assigned to a number of flowering plants (Magnoliophyta) were also identified (Table II), with four OTUs from King George Island and one from the Antarctic Peninsula region. The alga Koliella longiseta had the highest number of reads, followed by Chlamydomonas nivalis. The most widespread taxon (present in four sites) was also K. longiseta.

\section{DISCUSSION}

Hodson et al. (2008) recognised two glacial ecosystems, supraglacial, including organisms living on the ice surface, and subglacial, including organisms living within the ice layers, with the former community being more diverse and abundant.

The sequence data obtained here revealed the presence of a quite diverse algal assemblage. Koliella longiseta, a freshwater species, was the most abundant OTU and was also present in four of the six glaciers glacial ice samples 


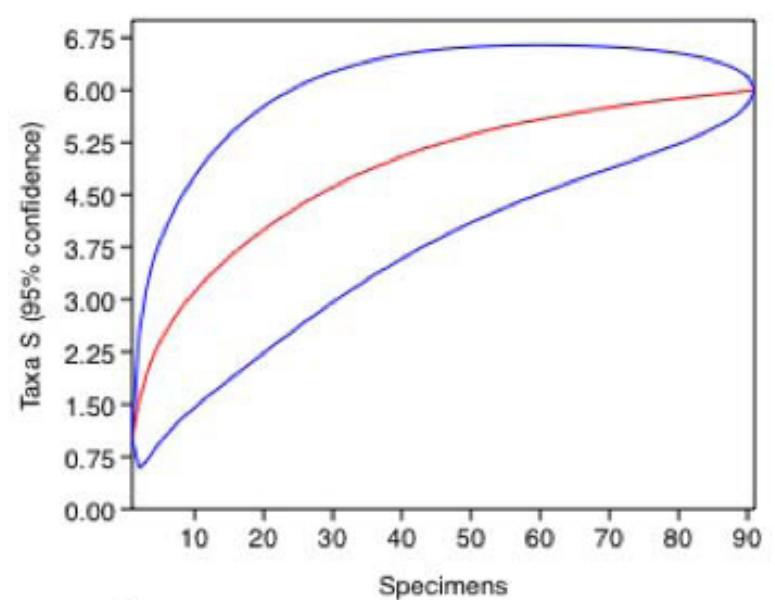

a

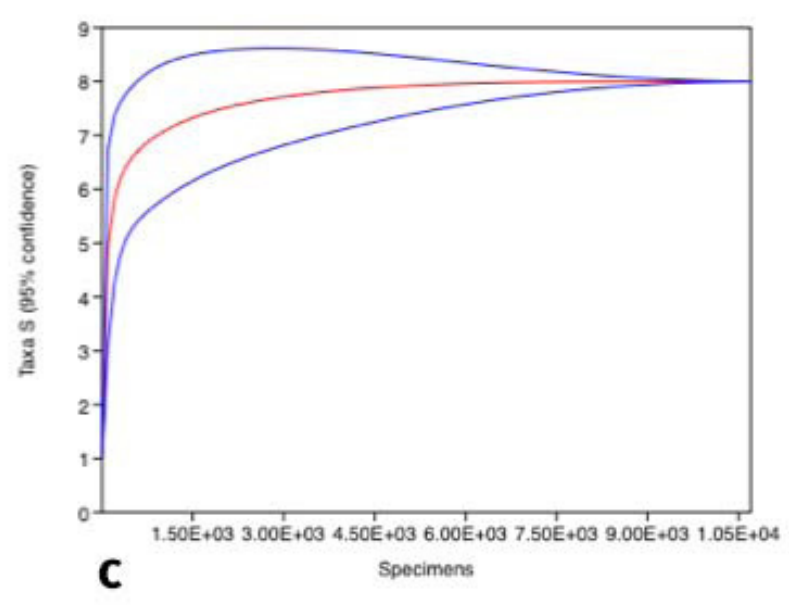

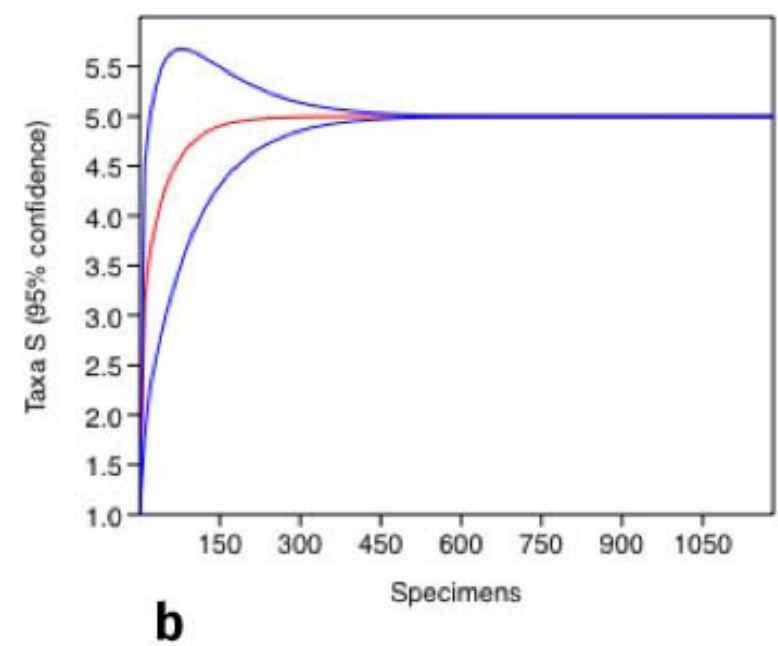

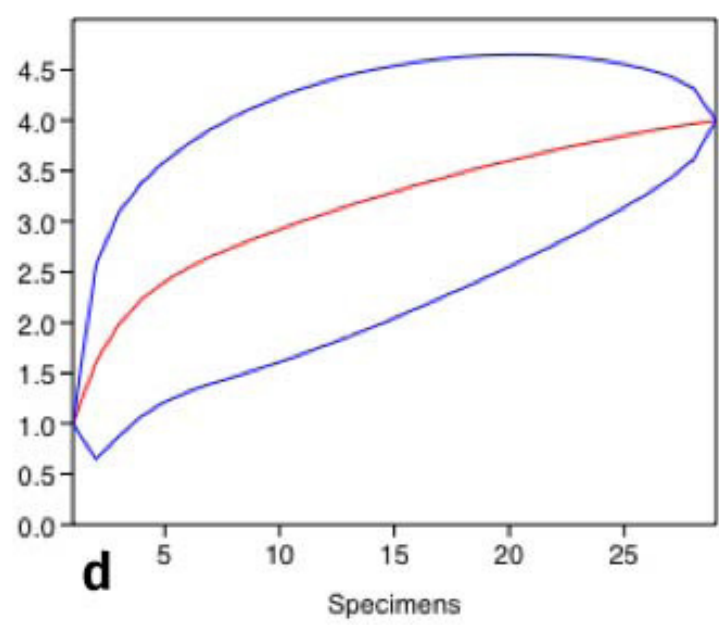

Figure. 2. Rarefaction curves for samples from (a) King George Island (b) Greenwich Island, (c) Antarctic Peninsula 2, (d) Arctowski Peninsula. Due to low numbers of taxa detected, it was not possible to generate rarefaction curves for the remaining samples. Blue lines represent $95 \%$ confidence limits.

obtained. The species was previously reported by Câmara et al. (2020) in a metabarcoding study of soil samples from Deception Island, also in the South Shetland Islands. Representatives of this genus are known to occur on alpine glacier surfaces and in snow (Hindák 1996). The second most abundant OTU was C. nivalis, a freshwater/ terrestrial species, which was present at two sampling locations. Clamydomonas nivalis is also a well-known snow alga (Remias et al. 2005) and has been reported from mountains and snowfields globally (Guiry \& Guiry 2021). Chloromonas alpina is also a snow alga, but has not previously been reported from Antarctica, with records from Europe, India and Australia/New Zealand (Guiry \& Guiry 2021). Myrmecia bisecta is a terrestrial alga that has been reported in a metabarcoding study on Deception Island (Câmara et al. 2020) and also in a traditional culture study of soil near Bellingshausen Station on King George Island (Andreyeva \& Kurbatova 2014). Raphidonema nivale is another snow alga that is also found in terrestrial and freshwater habitats, with wide occurrence in Europe, North and South America, Asia and Australia (Guiry \& Guiry 2021), and 
Table II. Assigned plant OTUs present in glacier ice obtained from six different sampling locations, with the number of reads for each. $\mathrm{KGI}=$ King George Island, Grw. = Greenwich Island, Pen1 = Antarctic Peninsula 1, Pen2= Antarctic Peninsula 2, Arctow.= Arctowski Peninsula and Living. = Livingston Island.

\begin{tabular}{|c|c|c|c|c|c|c|}
\hline TAXA & KGI & Grw. & Pen. 1 & Pen. 2 & Arctow. & Livin. \\
\hline \multicolumn{7}{|l|}{ Phylum Chlorophyta } \\
\hline Chlamydomonadales & 0 & 151 & 0 & 14 & 01 & 0 \\
\hline Chlamydomonas nivalis (F.A. Bauer) Wille & 0 & 685 & 0 & 1074 & 0 & 0 \\
\hline \multicolumn{7}{|l|}{ Chlorelalles } \\
\hline Chloromonas alpina Wille & 0 & 0 & 0 & 62 & 0 & 0 \\
\hline \multicolumn{7}{|l|}{ Prasiolales } \\
\hline Myrmecia bisecta Reisigl & 0 & 18 & 0 & 0 & 0 & 0 \\
\hline Koliella longiseta (Vischer) Hindák & 0 & 307 & 203 & 9209 & 11 & 0 \\
\hline Raphidonema nivale Lagerheim & 0 & 0 & 0 & 249 & 0 & 0 \\
\hline \multicolumn{7}{|l|}{ Ulotrichales } \\
\hline Chlorothrix sp. & 03 & 32 & 0 & 166 & 0 & 0 \\
\hline Monostroma angicava Kjellman & 0 & 0 & 0 & 0 & 0 & 20 \\
\hline Planophila sp. & 0 & 0 & 0 & 0 & 2 & 0 \\
\hline Ulothrix sp. & 0 & 0 & 0 & 4 & 0 & 0 \\
\hline Urospora sp. & 23 & 0 & 0 & 99 & 0 & 0 \\
\hline \multicolumn{7}{|l|}{ Phylum Magnoliophyta } \\
\hline \multicolumn{7}{|l|}{ Fabaceae } \\
\hline Cenostigma sp. & 3 & 0 & 0 & 0 & 0 & 0 \\
\hline \multicolumn{7}{|l|}{ Fagaceae } \\
\hline Nothofagus pumilio (Poepp. \& Endl.) Krasser & 56 & 0 & 0 & 0 & 0 & 0 \\
\hline \multicolumn{7}{|l|}{ Myrtaceae } \\
\hline Eugenia boliviana (D. Legrand) Mattos & 5 & 0 & 0 & 0 & 0 & 0 \\
\hline \multicolumn{7}{|l|}{ Plantaginaceae } \\
\hline Plantago lagopus L. & 0 & 0 & 0 & 0 & 15 & 0 \\
\hline \multicolumn{7}{|l|}{ Rosaceae } \\
\hline Malus sp. & 1 & 0 & 0 & 0 & 0 & 0 \\
\hline
\end{tabular}

again recorded through metabarcoding in soil on Deception Island (Câmara et al. 2020).

Among the Ulotrichales, Chlorothrix is a genus of marine algae which has only three European species recognised. DNA sequences assigned to this genus have recently been reported from Deception Island (Câmara et al. 2020). Monostroma angicava is also a marine species, reported from Japan, China, Korea and Norway but not previously from Antarctica. The closely related species $M$. kuroshiense F. Bast. and $M$. nitidum Wittrock are widely cultivated in Asia as food and have been used for treating viral infections (Kazłowski et al. 2012). Planophila is a genus of terrestrial or subaerial algae with only three recognised European species, although again reported in soil from Deception Island (Câmara et al. 2020). The genus Ulothrix includes about 39 accepted species, with representatives occurring in both marine and freshwater environments, cosmopolitan in temperate and colder regions (Guiry \& Guiry 2021), and sequences assigned to this genus have again been reported in soil from 

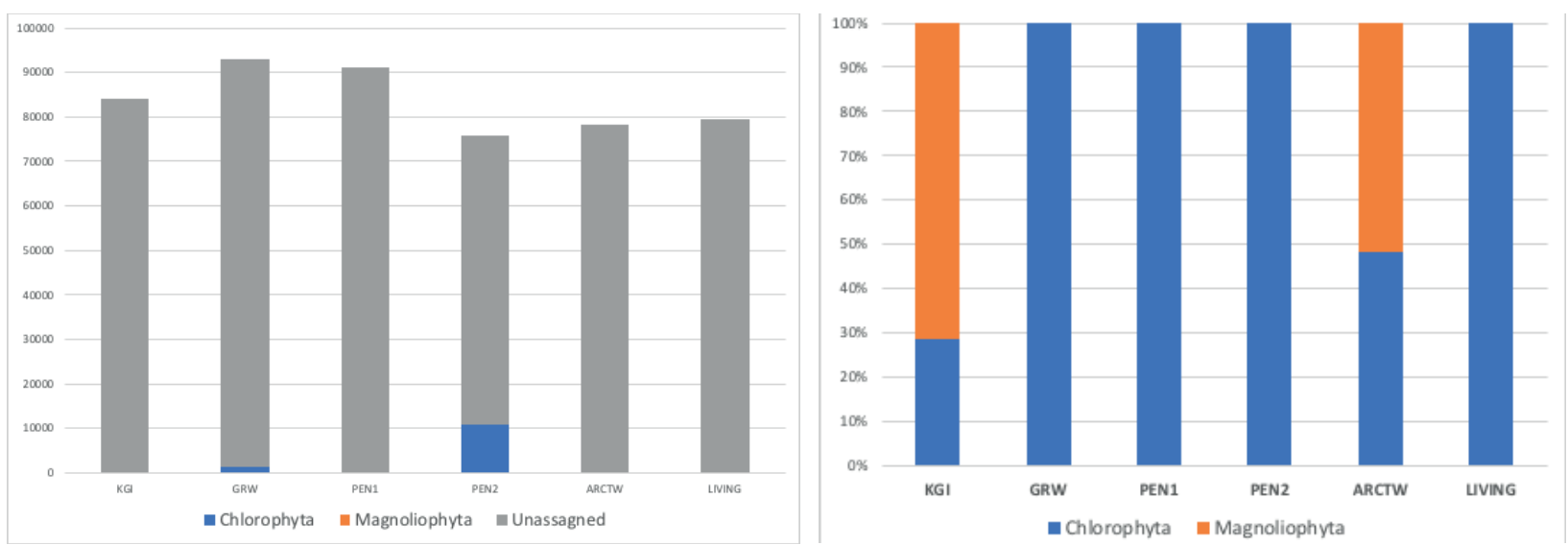

Figure 3. Histogram showing a) Tthe total number of reads obtained from each sampling site, including unassigned reads; and b) Percentage of groups represented, with the exclusion of unassigned reads.

Deception Island (Câmara et al. 2020), Ulothrix australis Gain has been previously reported from the Antarctic Peninsula (Papenfuss 1964). Urospora is a widespread marine genus with about 10 accepted species, including reports from the Arctic (Lee 1980), and with the species U. penicilliformis (Roth) Areschoug reported from the Antarctic Peninsula, Wilkes Land and the South Shetland Islands (Papenfuss 1964). The presence of sequences assigned to marine species could suggest seawater contamination although. As the studied glaciers are all coastal and the sampled ice surfaces were cleaned before DNA extraction, it is also possible that organisms (or propagules or fragments) were transferred in marine aerosols and became trapped in the ice.

Among the sequences assigned to flowering plants (Magnoliophyta), the most abundant OTU was the Fagaceae Nothofagus pumilio, a southern beech tree species native to the Andes of Patagonia, Tierra del Fuego and Navarino Island, where it is widespread and abundant. Pollen of this tree genus is widely reported in palynological studies of both ice and sediment cores obtained in Antarctica. The Plantaginaceae Plantago lagopus is a herb distributed in Europe, Asia and South America and used as a herbal tea and in medication for blood pressure
(Galisteo et al. 2005). Eugenia boliviana an endemic Mytaceae from the Bolivian (Andes) and Southern Brazil, Cenostigma is a neotropical legume genus with medicinal uses and the Rosaceae Malus (apple) is a widely cultivated for food (Jackson 2003). None of these taxa are considered as invasive, and the association of several with food or medicinal uses may suggest a human role in their presence in the current study. This inference may also be supported by the majority of flowering plant OTUs being found on King George Island, which is one of the most intensively human impacted locations in Antarctica. Indeed, the Malus OTU was present in ice obtained very close to the Brazilian Antarctic Station Comandante Ferraz.

The presence of DNA assigned to OTUs of flowering plants most likely reflects the presence of pollen or tissue fragments, or brought by humans, especially taxa used as food.

\section{CONCLUSIONS}

This study is the first to use a metabarcoding approach to assess DNA sequence diversity present in Antarctic glacial ice. The data obtained confirm the presence of Viridiplantae DNA in the ice. The OTU diversity detected suggests that the 
ice may contain a community of green algae, though cannot differentiate whether members of this are active or viable, or are represented by preserved DNA. Chlorophyta records include cold environment taxa not previously reported from Antarctica. The presence of DNA assigned to OTUs of flowering plants most likely reflects the presence of pollen or tissue fragments, or an association with human contamination.

\section{Acknowledgments}

This study received financial support from Conselho Nacional de Desenvolvimento Científico e Tecnológico (CNPq), PROANTAR, Fundação de Amparo à Pesquisa do Estado de Minas Gerais (FAPEMIG), Coordenação de Aperfeiçoamento de Pessoal de Nível Superior Brasil (CAPES), INCT Criosfera 2. P. Convey is supported by NERC core funding to the British Antarctic Survey's 'Biodiversity, Evolution and Adaptation' Team. Thanks also to congresswoman Jô Moraes and the Biological Sciences Institute at University of Brasilia. We thank the Brazilian Navy and Air Force.

\section{REFERENCES}

ABYZOV SS. 1993. Microorganisms in the Antarctic ice. In: Friedmann El (Ed), Antarctic microbiology. Wiley, New York, p. 265-295.

ANDREYEVA VM \& KURBATOVA LE. 2014. Terrestrial and aerophilic nonmotile green microalgae (Chlorophyta) from regions of investigation of Russian Antarctic expedition. Novosti Sist Nizsh Rast 48: 12-26. https://doi. org/10.31111/nsnr/2014.48.12.

ANESIO AM, HODSON AJ, FRITZ A, PSENNER R \& SATTLER B. 2009. High microbial activity on glaciers: importance to the global carbon cycle. Global Change Biol 15: 955-960.

ANESIO AM \& LAYBOURN-PARRY J. 2012. Glaciers and ice sheets as a biome. Trends Ecol Evol 27: 219-225.

BANCHI E, AMETRANO CG, GRECO S, STANKOVIĆ D, MUGGIA L, \& PALLAVICINI A. 2020. PLANiTS: a curated sequence reference dataset for plant ITS DNA metabarcoding. Database 2020: baz155.

BARNES MA \& TURNER CR. 2015. The ecology of environmental DNA and implications for conservation genetics. Conserv Genet 17: 1-17. DOI 10.1007/s10592-015-0775-4.
BOKULICH NA, KAEHLER BD, RIDEOUT JR, DILLON M, BOYLERN E, KNIGHT R, HUTTLEY GA \& CAPORASO JG. 2018. Optimizing taxonomic classification of marker-gene amplicon sequences with QIIME 2's q2-feature-classifier plugin. Microbiome 6: 90-107. https://doi.org/10.1186/ s40168-018-0470-z.

BOKULICH NA, SUBRAMANIAN S, FAITH JJ, GEVERS D, GORDON J, KNIGHT R, MILLS DA \& CAPORASO JG. 2013. Quality-filtering vastly improves diversity estimates from Illumina amplicon sequencing. Nat Methods 10: 57-59. https:// doi.org/10.1038/nmeth.2276.

BOLYEN E ET AL. 2019. Reproducible, interactive, scalable and extensible microbiome data science using QIIME 2. Nature Biotechnology 37: 852-857. https://doi. org/10.1038/s41587-019-0209-9.

CÂMARA PEAS, CARVALHO-SILVA M, PINTO OHB, AMORIM ET, HENRIQUES DK, SILVA TH, PELLIZZARI F, CONVEY P \& ROSA LH. 2020. Diversity and eEcology of Chlorophyta (Viridiplantae) aAssemblages in pProtected and nNonprotected sSites in Deception Island (Antarctica, South Shetland Islands) aAssessed uUsing an NGS aApproach. Microb Ecol https://doi.org/10.1007/s00248-020-01584-9.

CHEN S ET AL. 2010. Validation of the ITS2 region as a novel DNA barcode for identifying medicinal plant species. PLoS One 5: e8613.

COOK JM, HODSON AJ, TAGGART AJ, MERNILD SH \& TRANTER M. 2017. "A predictive model for the spectral "bioalbedo" of 30 snow". J Geophys Res Earth Surf 122(1): doi:10.1002/2016JF003932.

DARLING JA \& MAHON AR. 2011. From molecules to management: adopting DNA-based methods for monitoring biological invasions in aquatic environments. Environ Res 111: 978-988. https://doi.org/10.1016/j. envres.2011.02.001.

DAVEY MP, NORMAN L, STERK P, HUETE-ORTEGA M, BUNBURY F, LOH B, STOCKTON S, PECK LS, CONVEY P, NEWSHAM KK \& SMITH AG. 2019. Snow algae communities in Antarctica: metabolic and taxonomic composition. New Phytol 222(3): 1242-1255. https://doi.org/10.1111/nph.15701.

DEINER K ET AL. 2017. Environmental DNA metabarcoding: Transforming how we survey animal and plant communities. Mol Ecol 26(21): 5872-5895.

DE MENEZES GCA ET AL. 2020. Fungi in glacial ice of Antarctica: diversity, distribution and bioprospecting of bioactive compounds. Extremophiles 24: 367-376 https:// doi.org/10.1007/s00792-020-01161-5.

ELZINGA A. 2012. Some aspects in the history of ice core drilling from IGY to EPICA, p. 86-115, In: Lüdecke, 
C, Tipton-Everett $L$ \& Lay $L$ (Eds), National and TransNational Agendas in Antarctic Research from the 1950s and Beyond. Columbus, Ohio: Byrd Polar Research Center, The Ohio State University, Technical Report No. 2011-01.

FOGHT J, AISLABIE J, TURNER S, BROWN CE, RYBURN J, SAUL DJ \& LAWSON W. 2004. Culturable bacteria in subglacial sediments and ice from two sSouthern Hhemisphere glaciers. Microb Ecol 47: 329-340

FRASER CI, CONNELL L, LEE CK \& CARY SC. 2018. Evidence of plant and animal communities at exposed and subglacial (cave) geothermal sites in Antarctica. Polar Biol 41: 417421. https://doi.org/10.1007/s00300-017-2198-9.

GALISTEO M, SÁNCHEZ M, VERA R, GONZÁLEZ M, ANGUERA A, DUARTE J \& ZARZUELO A. 2005. A diet supplemented with husks of Plantago ovata reduces the development of endothelial dysfunction, hypertension, and obesity by affecting adiponectin and tnf-alpha in obese zucker rats. J Nutr 135: 2399-2404.

GARRIDO-BENAVENT I, PÉREZ-ORTEGA S, DURÁN J, ASCASO C, POINTING SB, RODRÍGUEZ-CIELOS R, NAVARRO F \& DE LOS RÍOS A. 2020. Differential cColonization and sSuccession of mMicrobial cCommunities in rRock and sSoil sSubstrates on a Maritime Antarctic gGlacier fForefield. Front Microbiol https://doi.org/10.3389/fmicb.2020.00126.

GINER CR, FORN I, ROMAC S, LOGARES RC \& MASSANA R. 2016. Environmental sSequencing pProvides rReasonable eEstimates of the rRelative aAbundance of sSpecific pPicoeukaryotes. App Environ Microbiol 82(15): 47574766. https://doi.org/10.1128/AEM.00560-16.

GUIRY MD \& GUIRY GM. 2021. AlgaeBase. World-wide electronic publication, National University of Ireland, Galway. https://www.algaebase.org; searched on 19 February 2021.

GUNDE-CIMERMAN N, SONJAK S, ZALAR P, FRISVAD JC, DIDERICHSEN B \& PLEMENITAŠ A. 2003. Extremophilic fungi in Aarctic ice: a relationship between adaptation to low temperature and water activity. Phys Chem Earth Parts A/B/C 28: 1273-1278.

HERING D, BORJA A, JONES J I, PONT D, BOETS P, BOUCHEZ A \& LEESE F. 2018. Implementation options for DNA-based identification into ecological status assessment under the European Water Framework Directive. Water Res 138: 192-205.

HINDÁK F. 1996. Kl'ú na ur ovanie nerozkonáren ch vláknit ch zelen ch rias (Ulotrichineae, Ulotrichales, Chlorophyceae). Bull. Slov. Bot. Spol. Pri SAV 1(Suppl):1-77
HODSON, A, ANESIO AM, TRANTER M, FOUNTAIN A, OSBORN M, PRISCU J, LAYBOURN-PARRY J \& SATTLER B. 2008. Glacial ecosystems. Ecol. Monogr 78: 41-67.

HODSON A, CAMERON K, BØGGILD C \& IRVINE-FYNN T. 2010. The structure, biological activity and biogeochemistry of cryoconite aggregates upon an Arctic valley glacier: Longyearbreen, Svalbard. J. Glaciol 56: 349-362.

JACKSON JE. 2003. Biology of apples and pears. Cambridge University Press, Cambridge.

JOSHI NA \& FASS JN. 2011. Sickle: A sliding-window, adaptive, quality-based trimming tool for FastQ files (Version 1.33) [Software]. https://github.com/najoshi/sickle.

KAZŁOWSKI B, CHIU Y-H, KAZŁOWSKA K, PAN C-L \& WU C-J. 2012. Prevention of Japanese encpalitis virus infections by low-degree-polymerisation sulfated saccharides from Garcilaria sp. and Monostroma nitidum. Food Chem doi:10.1016/j.foodchem.2012.01.106.

LEE RKS. 1980. A catalogue of the marine algae of the Canadian Arctic. National Museum of Canada Publications in Botany 9: 1-82.

LELIAERT F, SMITH DR, MOREAU H, HERRON MD, VERBRUGGEN H, DELWICHE CF \& DE CLERCK O. 2012. Phylogeny and molecular evolution of the green algae. CRC Crit Rev Plant Sci 31: 1-46. https://doi.org/ 10.1080/07352689.2011.615705.

LEVER MA, TORTI A, EICKENBUSCH P, MICHAUD AB, ŠANTLTEMKIV T \& JØRGENSEN BB. 2015. A modular method for the extraction of DNA and RNA, and the separation of DNA pools from diverse environmental sample types. Front Microbiol 6: 476.

LUTZ S, ANESIO AM, EDWARDS A \& BENNING LG. 2017. Linking microbial diversity and functionality of Aarctic glacial surface habitats. Environ. Microbiol. 19: 551-565. doi: 10.1111/1462-2920.13494.

MARGESIN R \& MITEVA V. 2011. Diversity and ecology of psychrophilic microorganisms. Res. Microbiol 162: 346-361.

MARGESIN R, ZACKE G \& SCHINNER F. 2002. Characterization of heterotrophic microorganisms in Alpine glacier cryoconite. Arct. Antarct. Alp. Res. 34: 88-93.

MEDINGER R, NOLTE V, PANDEY RV, JOST S, OTTENWÄLDER B, SCHLÖTTERER C \& BOENIGK. 2010. Diversity in a hidden world: potential and limitation of next-generation sequencing for surveys of molecular diversity of eukaryotic microorganisms. Molec Ecol 19: 32-40.

MITEVA VI \& BRENCHLEY JE. 2005. Detection and isolation of ultrasmall microorganisms from a 120,000-year-old Greenland glacier ice core. Appl Environ Microbiol 71: 7806-7818. 
ONUMA Y, TAKEUCHI N, TANAKA S, NAGATSUKA N, NIWANO M \& AOKI T. 2018. Observations and modelling of algal growth on a snowpack in north-western Greenland. The cryosphere 12: 2147-2158.

PAPENFUSS GF. 1964. Catalogue and bibliography of Antarctic and Sub-Antarctic benthic marine algae. In: Lee MO (Ed), Antarctic Research Series. Volume 1. Bibliography of the Antarctic Seas, p. 1-76. Washington D.C.: American Geophysical Union.

PERINI L, GOSTINČAR C \& GUNDE-CIMERMAN N. 2019. Fungal and bacterial diversity of Svalbard subglacial ice. Sci Rep 9: 1-15.

PORAZINSKA, DL, FOUNTAIN AG, NYLEN TH, TRANTER M, VIRGINIA RA \& WALL DH. 2004. The biodiversity and biogeochemistry of cryoconite holes from McMurdo Dry Valley glaciers, Antarctica. Arct. Antarct. Alp. Res. 36: 84-91.

PRICE PB. 2000. A habitat for psychrophiles in deep Antarctic ice. Proc Natl Acad Sci USA 97: 1247-1251.

REMIAS D, LÜTZ-MEINDL U \& LÜTZ 1737829828 C. 2005. Photosynthesis, pigments and ultrastructure of the alpine snow alga Chlamydomonas nivalis. Eur J Phycol 40: 259-268.

RICHARDSON RT, LIN CH, SPONSLER DB, QUIJIA JO, GOODELL K \& JOHNSON RM. 2015. Application of ITS2 metabarcoding to determine the provenance of pollen collected by honey bees in an agroecosystem. Appl Plant Sci 3: 1400066.

RIPPIN M, BORCHHARDT N, WILLIAMS L, COLESIE C, JUNG P, BÜDEL B, KARSTEN U \& BECKER B. 2018. Genus richness of microalgae and Cyanobacteria in biological soil crusts from Svalbard and Livingston Island: morphological versus molecular approaches. Polar Biol 41: 909-923. https://doi.org/10.1007/s00300-018-2252-2.

ROGNES T, FLOURI T, NICHOLS B, QUINCE C \& MAHÉ F. 2016. VSEARCH: A versatile open source tool for metagenomics. Peer) 2016: 1-22. https://doi.org/10.7717/peerj.2584.

RUPPERT K, KLINE RJ \& RAHMAN MS. 2019. Past, present, and future perspectives of environmental DNA (eDNA) metabarcoding: A systematic review in methods, monitoring, and applications of global eDNA. Glob Ecol Conserv 17: 1-29. https://doi.org/10.1016/j.gecco.2019. e00547.

SADAIAPPAN B, KANNAN S, PALANIAPPAN S, MANIKKAM R, RAMASAMY B, ANILKUMAR N \& SUBRAMANIAN M. 2020. Metagenomic 16S rDNA amplicon data of microbial diversity and its predicted metabolic functions in the Southern Ocean (Antarctic). Data in Brief. Volume 28: 104876.
SANYAL A, ANTONY R, SAMUI G \& THAMBAN M. 2018. Microbial communities and their potential for degradation of dissolved organic carbon in cryoconite role environments of Himalaya and Antarctica. Microbiol Res 208: 32-42.

SIDDIQUI KS \& CAVICCHIOLI R. 2006. Cold-adapted enzymes. Annu Rev Biochem 75: 403-433.

SHERIDAN PP, MITEVA VI \& BRENCHLEY JE. 2003. Phylogenetic analysis of anaerobic psychrophilic enrichment cultures obtained from a Greenland glacier ice core. Appl Environ Microbiol 69: 2153-2160.

STIBAL M, SABACKÁ M \& KATOVSKÁ K. 2006. Microbial communities on glacier surfaces in Svalbard: impact of physical and chemical properties on abundance and structure of cyanobacteria and algae. Microb Ecol 52: 644-654.

STIBAL M ET AL. 2017. Algae drive enhanced darkening of bare ice on the Greenland ice sheet. Geophys Res Lett 44: 11463-11471. https://doi.org/10.1002/2017GL075958.

TAKEUCHI N, FUJISAWA Y, KADOTA T, TANAKA S, MIYAIRI M, SHIRAKAWA T, KUSAKA R, FEDOROV AN, KONSTANTINOV P \& OHATA T. 2015. The effect of impurities on the surface melt of a glacier in the Suntar-Khayata mountain range, Russian Siberia. Front Earth Sci 3: 82. doi: 10.3389/ feart.2015.00082.

TURNER J, COLWELL SR, MARSHALL GJ, LACHLAN-COPE TA, CARLETON AM, JONES PD, LAGUN V, REID PA \& IAGOVKINA S. 2005. Antarctic climate change during the last 50 years. Int J Climatol 25: 279-294.

WEBER AA \& PAWLOWSKI J. 2013. Can abundance of protists be inferred from sequence data: a case study of Foraminifera. Plos One 8: e56739.

YALLOP ML \& ANESIO AM. 2010. Benthic diatom flora in supraglacial habitats: a generic-level comparison. Ann Glaciol 51: 15-22.

YOSHIMURA Y, KOHSHIMA S \& OHTANI S. 1997. A community of snow algae on a Himalayan glacier: change of algal biomass and community structure with altitude. Arct Alp Res 29: 126-137. DOI: 10.2307/1551843.

\section{How to cite 10.1590/0001-3765202220201736. \\ Manuscript received on November 7, 2020; accepted for publication on June 4, 2021}

CÂMARA PEAS, MENEZES GCA, PINTO OHB, SILVA MC, CONVEY P \& ROSA LH. 2022. Using metabarcoding to assess Viridiplantae sequence diversity present in Antarctic glacial ice. An Acad Bras Cienc 94: e20201736. DOI 
PAULO E.A.S. CÂMARA ${ }^{1,2}$

https://orcid.org/0000-0002-3944-996X

\section{GRACIELE C.A. MENEZES ${ }^{3}$}

https://orcid.org/0000-0002-9427-1893

OTAVIO H.B. PINTO 4

https://orcid.org/0000-0002-8382-2987

MICHELINE C. SILVA ${ }^{1}$

https://orcid.org/0000-0002-2389-3804

\section{PETER CONVEY 5,6}

https://orcid.org/0000-0001-8497-9903

\section{LUIZ H. ROSA ${ }^{3}$}

https://orcid.org/0000-0001-9749-5182

${ }^{1}$ Universidade de Brasília, Departamento de Botânica, Instituto de Ciências Biológicas, Campus Universitário Darcy Ribeiro, s/n, 70910-900 Brasília, DF, Brazil

${ }^{2}$ Universidade Federal de Santa Catarina, Pós-graduação em Plantas, Fungos e Algas, Campus Universitário, s/n, Sala 208, Bloco E, Córrego Grande, 88040-900 Florianópolis, SC, Brazil ${ }^{3}$ Universidade Federal de Minas Gerais, Departamento de Microbiologia, Instituto de Ciências Biológicas, Av. Antônio Carlos, 6627, Pampulha, 31270-000 Belo Horizonte, MG, Brazil
${ }^{4}$ Universidade de Brasília, Departamento de Biologia Celular, Instituto de Ciências Biológicas, Campus Universitário Darcy Ribeiro, s/n, 70910-000 Brasília, DF, Brazil

${ }^{5}$ British Antarctic Survey, NERC, High Cross, Madingley Road, Cambridge CB3 OET, U.K.

${ }^{6}$ University of Johannesburg, Department of Zoology, PO

Box 524, Auckland Park 2006, Johannesburg, South Africa

Correspondence to: Paulo Eduardo Aguiar Saraiva Câmara

E-mail: paducamara@gmail.com

\section{Author contributions}

PEASC, LHR and PC designed the experiment, GCAM performed lab work, OHBP and PEASC did the bioinformatic and PEASC, MCS, PC and LHR did data analyses. All author contributed equally to the writing of this manuscript.

\section{(cc) BY}

